\title{
Regulation of blood-testis barrier by actin binding proteins and protein kinases
}

\author{
Nan Li, Elizabeth I Tang and C Yan Cheng \\ The Mary M. Wohlford Laboratory for Male Contraceptive Research, Center for Biomedical Research, \\ Population Council, 1230 York Avenue, New York, New York 10065, USA \\ Correspondence should be addressed to C Y Cheng; Email: Y-Cheng@popcbr.rockefeller.edu; ccheng@mail.rockefeller.edu
}

\begin{abstract}
The blood-testis barrier (BTB) is an important ultrastructure in the testis, since the onset of meiosis and spermiogenesis coincides with the establishment of a functional barrier in rodents and humans. It is also noted that a delay in the assembly of a functional BTB following treatment of neonatal rats with drugs such as diethylstilbestrol or adjudin also delays the first wave of spermiation. While the BTB is one of the tightest blood-tissue barriers, it undergoes extensive remodeling, in particular, at stage VIII of the epithelial cycle to facilitate the transport of preleptotene spermatocytes connected in clones across the immunological barrier. Without this timely transport of preleptotene spermatocytes derived from type B spermatogonia, meiosis will be arrested, causing aspermatogenesis. Yet the biology and regulation of the BTB remains largely unexplored since the morphological studies in the 1970s. Recent studies, however, have shed new light on the biology of the BTB. Herein, we critically evaluate some of these findings, illustrating that the Sertoli cell BTB is regulated by actin-binding proteins (ABPs), likely supported by non-receptor protein kinases, to modulate the organization of actin microfilament bundles at the site. Furthermore, microtubule-based cytoskeleton is also working in concert with the actin-based cytoskeleton to confer BTB dynamics. This timely review provides an update on the unique biology and regulation of the BTB based on the latest findings in the field, focusing on the role of ABPs and non-receptor protein kinases.
\end{abstract}

Reproduction (2016) 151 R29-R41

\section{Introduction}

The concept of the blood-testis barrier (BTB) dates back to more than 100 years ago when dyes administered to rodents failed to stain the brain and the testis, illustrating the presence of the blood-brain barrier (BBB) and the BTB in mammals (for reviews, see Setchell (2008), Cheng \& Mruk (2012) and Mruk \& Cheng (2015)). Subsequent studies have shown that the BTB is very different from the BBB and other blood-tissue barriers, such as the blood-retinal barrier, since these other blood-tissue barriers are contributed almost exclusively by the tight junction (TJ) barrier between endothelial cells of the microvessels, such as those found behind the brain and the retina (for reviews, see Campbell \& Humphries 2012, Easton 2012). Instead, the BTB is constituted by specialized junctions between adjacent Sertoli cells located near the basement membrane in the seminiferous epithelium which is composed of actinbased TJ, basal ectoplasmic specialization (ES), and gap junction (GJ), as well as intermediate filament-based desmosome (for reviews, see Mruk \& Cheng (2004), Pelletier (2011) and Cheng \& Mruk (2012)) (Fig. 1). In short, endothelial TJ barrier of the microvessels located in the interstitium between seminiferous tubules contributes virtually no barrier function to the BTB. Interestingly, since the initial discovery of the BTB, relatively few functional studies were performed beyond the collection and quantification of constituents in biological fluids in the seminiferous tubule, rete testis, and interstitial fluid for comparison to blood plasma and/or serum. Findings from these studies have illustrated the significance of the BTB in the mammalian testis by restricting the flow of ions, proteins, electrolytes, sugars, and other biomolecules across the barrier (for a review, see Setchell \& Waites (1975)). Morphological studies performed in the 1970s have shown that the BTB physically divides the seminiferous epithelium into two functional compartments: the basal and the adluminal (apical) compartments. As such, the events of mitosis for self-renewal of spermatogonial stem cells (SSCs) and undifferentiated spermatogonia, and the differentiation of type B spermatogonia to preleptotene spermatocytes all take place outside the BTB at the basal compartment. However, meiosis I/II and the entire events of postmeiotic spermatid development (i.e., spermiogenesis) and the release of sperm at spermiation all take place behind the BTB in a specialized microenvironment known as the adluminal compartment (Fig. 2). While the BTB is considered to be one of the tightest blood-tissue barriers, it continuously remodels throughout the 


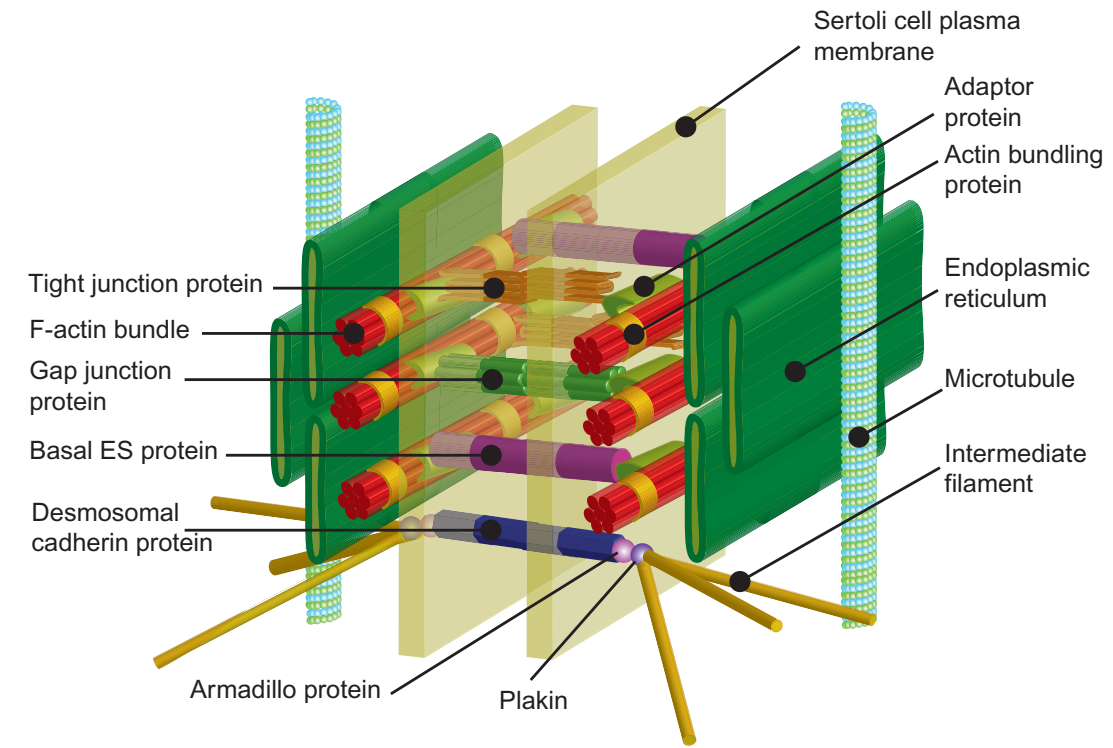

Figure 1 A schematic drawing illustrating the various junction types and their structural and spatial relationship to the actin- and MT-based cytoskeletons at the Sertoli cell BTB. In the mammalian testis, such as in rodents, the BTB is constituted by TJ, basal ES, and GJ that utilize actin microfilaments for their attachment, as well as intermediate filament-based desmosome, as shown in this 3-D schematic drawing. Endothelial TJ in microvessels located in the interstitium contributes virtually no barrier function to the BTB. The corresponding protein complexes of TJ (e.g., occludin-ZO-1), basal ES (e.g., N-cadherin- $\beta$-catenin), GJ (e.g., connexin43-plakophilin-2), and desmosome (e.g., desmoglein-2-plakoglobin-2/ desmoplakin) confer cell adhesion between adjacent Sertoli cells. Actin microfilaments are polarized structures and are arranged as bundles, which together with the nearby polarized MT also provide the track for the transport of germ cells in particular spermatids and other organelles (e.g., phagosomes and endocytic vesicles) across the seminiferous epithelium besides conferring unparalleled adhesive strength to the BTB during the epithelial cycle of spermatogenesis.

epithelial cycle of spermatogenesis to allow the entry of selected substances/biomolecules necessary to support meiosis I/II and spermiogenesis. It also restructures itself to allow the transport of preleptotene spermatocytes across the barrier at stage VIII of the epithelial cycle so that these spermatocytes enter the adluminal compartment to be differentiated into leptotene, zygotene, and pachytene spermatocytes to prepare for meiosis I/II which takes place at stages XII and XIV in the mouse and rat respectively (for reviews, see Hess \& de Franca (2008) and Cheng \& Mruk (2012)). In this context, it is noted that the epithelial cycle of spermatogenesis in the mouse and rat testis is divided into stages I-XII and I-XIV respectively (for reviews, see Clermont (1972), Parvinen (1982), Hess \& de Franca (2008) and Xiao et al. (2014a)).

Since the 1970s, when the ultrastructures of the BTB were reported in detail (Fawcett et al. 1970, Fawcett 1975, Setchell \& Waites 1975, Russell 1977a, 1978), few studies have examined the role of the BTB in spermatogenesis until this past decade. There are some incentives to better understand BTB functionally in recent years among investigators who seek to develop male contraceptives that exert their effects on germ cell maturation and/or meiosis behind the BTB, since it poses a barrier that limits the uptake of drugs into the testis (Grima et al. 2001, Hild et al. 2001, Cheng et al. 2005, Hild et al. 2007, Tash et al. 2008, Amory et al. 2011, Chung et al. 2011). Studies have shown that multiple drug transporters are highly expressed by Sertoli cells which thus significantly reduce the bioavailability of many potential contraceptive drugs under investigation and development (for reviews, see Mruk et al. (2011) and Cheng \& Mruk (2012)). In short, the BTB not only poses an important barrier to protect harmful substances from reaching the adluminal compartment to perturb spermatogenesis but also restricts the access of potential male contraceptives to disrupt spermatogenesis transiently, rendering these contraceptives less effective. This thus potentiates the toxicity of these contraceptives because higher concentrations of these drugs are required to be administered. In this review, we highlight some of the latest developments in the field regarding the biology of the BTB, since several recent reviews have addressed some other interesting aspects of the BTB biology (for reviews, see Mital et al. 2011, Pelletier 2011, Cheng \& Mruk 2012, Franca et al. 2012, Kaur et al. 2014, Mruk \& Cheng 2015). In particular, we will focus on the regulation of Sertoli cell cytoskeletons by actin-binding proteins (ABPs), the intrinsic activity of which may be modulated through non-receptor protein kinases to regulate the plasticity of the barrier.

\section{Structure and function of the BTB}

\section{Structural features}

Unlike other blood-tissue barrier, TJs at the BTB formed between adjacent Sertoli cells near the basement 


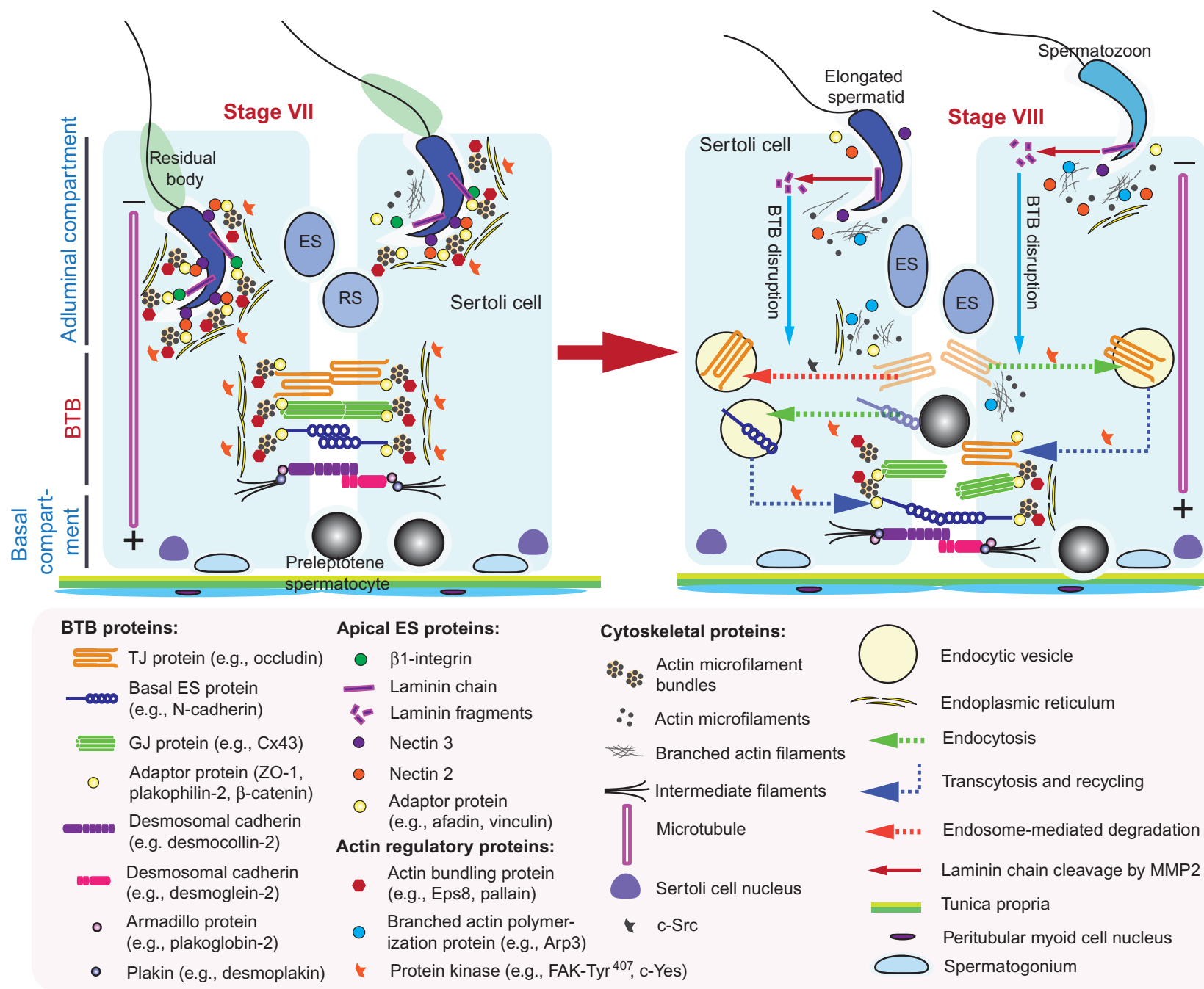

Figure 2 A schematic drawing illustrating the molecular mechanism by which preleptotene spermatocytes are transported across BTB at stage VIII of the epithelial cycle. The cross-section of a stage VII seminiferous tubule on the left panel illustrates that the intact BTB is conferred by adhesion protein complexes of the actin-based TJ, basal ES, and GJ, as well as the intermediate filament-based desmosome. The apical ES is also intact which is conferred by the corresponding adhesion complexes of nectin-afadin and $\beta 1$-integrin-laminins. Preleptotene spermatocytes transformed from type B spermatogonia are first detected at stage VII and are being transported across the BTB, when apical ES also undergoes degeneration to prepare for spermiation as noted in a stage VIII tubule shown on the right panel. Biologically active laminin fragments (e.g., F5 peptide) generated by MMP2-induced proteolytic cleavage of laminin chains at the apical ES induce BTB restructuring in which TJ (e.g., occludin), basal ES (e.g., $\mathrm{N}$-cadherin), GJ (e.g., connexin 43), and desmosome (e.g., desmoglein 2) proteins undergo endocytic vesicle-mediated endocytosis, transcytosis, and recycling. In this way, the 'old' BTB proteins located above the preleptotene spermatocytes being transported across the barrier can be recycled to assemble a 'new' BTB behind these germ cells, prior to the degeneration of the 'old' BTB. As such, the events of spermiation and BTB remodeling which allow the release of sperm and the transport of preleptotene spermatocytes that occur at the opposite ends of the epithelium and take place simultaneously at stage VIII of the cycle, respectively, are functionally supporting one another.

membrane of the seminiferous epithelium are surrounded by actin filament bundles, found on both sides of the Sertoli cell, that lie perpendicular to the Sertoli cell plasma membrane and sandwiched between the cisternae of endoplasmic reticulum and the plasma membrane (for reviews, see Fawcett (1975) and Setchell \& Waites (1975)), making the BTB a unique blood-tissue barrier (Fig. 1). These two arrays of actin microfilament bundles that enforce and support the TJ between adjacent Sertoli cells create a unique ultrastructure known as the ES, and due to its restrictive presence near the basal compartment, it is called basal ES (Russell 1977a, 1978). Also, ES is found at the Sertoli-spermatid interface, similar to the basal ES ultrastructurally except that the actin microfilament bundles are only detected in the Sertoli cell, and it is restrictively present in the apical compartment; thus it is named apical ES (Russell 1977b). Subsequent studies have shown that the actin microfilament bundles at the basal ES also support the function of GJ, and as such, the BTB is comprised by both TJ and GJ and are intimately supported by actin microfilaments of the basal ES (for reviews, see Vogl et al. (2008) and 
Cheng \& Mruk (2010, 2012)). Thus, in order to better understand the biology of the BTB, the regulation of the Sertoli cell cytoskeletons that constitute the BTB must be elucidated. It is obvious that remodeling of the BTB to support preleptotene spermatocyte transport and the selective entry of biomolecules into the adluminal compartment requires rapid conversion of the actin microfilaments between their 'bundled' to 'unbundled/ branched' configuration. In the sections below, recent findings regarding cytoskeletal remodeling regulated by different ABPs are evaluated.

\section{Functions of the BTB}

BTB provides a barrier that restricts the flow of small biomolecules, ions, sugars, and other substances including water between the basal and the apical compartments (transcellular barrier), and also between adjacent Sertoli cells (paracellular barrier). Studies have compared the composition of the seminiferous tubule fluid recovered from the tubule lumen or rete testis fluid in the rete testis compartment vs the interstitial fluid in the interstitial space and blood plasma, and showed that they are considerably different (Setchell \& Waites 1975, Setchell 1980, Turner et al. 1984). It was reported that the protein content of rete testis fluid, seminiferous tubule fluid, interstitial fluid, and serum of adult rats was about $0.6,30,40$, and $60 \mathrm{mg} / \mathrm{ml}$ respectively (Cheng et al. 1986). These differences are contributed by the BTB as well as by the ability of the epithelial cells of different compartments (e.g., rete testis and seminiferous tubules) to secrete (or re-absorb) different proteins and fluid into (or from) the lumen. Besides these obvious functions of the BTB, it also confers polarity to the Sertoli cell in the seminiferous epithelium. One of the most typical features of Sertoli cell polarity is the conspicuous presence of the nucleus near the basement membrane. Other organelles, such as phagosomes and Golgi apparatus, are also located mostly near the basolateral region of the Sertoli cell. The BTB also physically divides the seminiferous epithelium into the apical and basal compartment in which the events of meiosis $1 / I I$ and spermiogenesis all take place in a specialized microenvironment, namely, the apical (adluminal) compartment. It is known that the BTB segregates post-meiotic spermatids from cells in the basal compartment (e.g., SSCs, undifferentiated and differentiated spermatogonia, and preleptotene spermatocytes) and cells in the interstitium (e.g., resident macrophages, Leydig cells, endothelial cells of the microvessels, and fibroblasts), thereby sequestering late stage spermatocyte- and spermatid-specific antigens from the systemic circulation. Studies have shown that the BTB likely contributes relatively little to confer the immune privilege status of the testis by sequestering germ cell antigens from the systemic circulation (for reviews, see O'Bryan \& Hedger (2008) and Meinhardt \& Hedger (2011)), since it is known that autoantigenic germ cells (e.g., SSC, spermatogonia and preleptotene spermatocytes) reside in the basal compartment, located outside the BTB (Yule et al. 1988). In fact, many cancer/testis antigens (most are products of oncogenes) are abundantly expressed by germ cells in the apical compartment (e.g., zygotene/ pachytene/diplotene spermatocytes, round/elongating/ elongated spermatids, and spermatozoa) as well as those in the basal compartment (for reviews, see Simpson et al. (2005) and Cheng et al. (2011)). It is of interest to note that the microenvironment in the apical compartment created by the BTB is essential to maintain meiosis and spermiogenesis, since irreversible disruption of the BTB is known to cause infertility, such as sterility caused by toxicants glycerol and cadmium (Setchell \& Waites 1970, Hew et al. 1993, Wiebe et al. 2000), and also a potential male contraceptive adjudin when used at an acute high dose (Mok et al. 2012), which are known to induce permanent BTB damage. Other studies have shown that the immune privilege status of the testis is likely contributed mostly by biological factors (e.g., cytokines) secreted by Sertoli cells (or primary cultures of Sertoli cells but not Sertoli cell line), making Sertoli cells a prime candidate to serve as immunosuppressive cells for allogeneic and also xenogeneic transplantation (Dufour et al. 2004, 2008, Mital et al. 2010, Kaur et al. 2013, 2014). In fact, recent studies have demonstrated successful long-term stability of Sertoli cell-based cell transplant therapy for several pathological conditions (Luca et al. 2013, 2015). In short, unlike other bloodtissue barriers which are conferred mostly by endothelial TJ barrier of microvessels, BTB is constituted by coexisting TJ, basal ES, and GJ, along with intermediate filament-based desmosome between adjacent Sertoli cells near the basement membrane in the epithelium of seminiferous tubules.

\section{Cytoskeletons of the BTB}

As briefly reviewed above, one of the most prominent features of the BTB vs other blood-tissue barriers by electron microscopy is the prominent presence of actin microfilament bundles and microtubules (MTs) between Sertoli cells near their cortical zone that constitute the barrier (Fig. 1) (for reviews, see Fawcett 1975, Vogl et al. 2008). Thus, it is envisioned that these two cytoskeletons are playing a crucial role in BTB physiology during the epithelial cycle (Tables 1 and 2). In fact, the significance of actin- and MT-based cytoskeletons in maintaining the ES and tubule integrity has been reported almost three decades ago in studies using toxicants that are known to disrupt actin or MT filaments (Russell et al. 1981, 1988). Studies using environmental toxicants (e.g., 2, 5-hexanedione and carbendazim) have also demonstrated that the MT-based cytoskeleton in Sertoli cells is the primary target of these toxicants. In short, 2, 5 -hexanedione and/or carbendazim induce germ cell 
Table 1 Actin binding proteins (ABPs) that regulate Sertoli cell actin-based cytoskeleton at the BTB ${ }^{\mathrm{a}}$.

\begin{tabular}{|c|c|c|c|c|}
\hline $\begin{array}{l}\text { Actin binding } \\
\text { protein (ABP) }\end{array}$ & $\begin{array}{l}\text { Mr in the } \\
\text { testis }(\mathrm{kDa})\end{array}$ & $\begin{array}{l}\text { Expression pattern in the seminiferous } \\
\text { epithelium during the epithelial cycle }\end{array}$ & Function at the BTB & $\begin{array}{l}\text { Phenotype(s) following } \\
\text { KO in mice }\end{array}$ \\
\hline Arp3 & 45 & $\begin{array}{l}\text { Expressed at the BTB in stage VII-IX tubules, } \\
\text { highest at stage VIII (Lie et al. 2010b) }\end{array}$ & $\begin{array}{l}\text { Induces branched actin } \\
\text { polymerization }\end{array}$ & $\begin{array}{l}\text { Arp3 KO mice died at blastocysts } \\
\text { stage (Vauti et al. 2007) }\end{array}$ \\
\hline Eps8 & 97 & $\begin{array}{l}\text { Highly expressed at the BTB in stage V-VI } \\
\text { (Lie et al. 2009b) }\end{array}$ & $\begin{array}{l}\text { Actin-barded end-capping } \\
\text { and -bundling }\end{array}$ & $\begin{array}{l}\text { Eps8 KO mice were healthy and } \\
\text { fertile (Scita et al. 1999) }\end{array}$ \\
\hline Espin & 110 & $\begin{array}{l}\text { Expressed in the basal compartment, } \\
\text { consistent with its localization at the BTB } \\
\text { (Bartles et al. 1996) }\end{array}$ & Actin bundling & $\begin{array}{l}\text { Espin KO mice were viable and } \\
\text { fertile (Revenu et al. 2012) }\end{array}$ \\
\hline Ezrin & 85 & $\begin{array}{l}\text { Expressed in all stages at the BTB except } \\
\text { stage IX (Gungor-Ordueri et al. 2014a) }\end{array}$ & $\begin{array}{l}\text { Actin-bundling, constituent } \\
\text { protein of intercellular } \\
\text { bridges }\end{array}$ & $\begin{array}{l}\text { Ezrin KO mice did not survive more } \\
\text { than } 1.5 \text { week after birth } \\
\text { (Saotome et al. 2004, } \\
\text { Tamura et al. 2005) }\end{array}$ \\
\hline Drebrin $\mathrm{E}$ & 110 & $\begin{array}{l}\text { Highly expressed at the BTB in stages IV-V } \\
\text { and considerably diminished in } \\
\text { stages VIII-XIV (Li et al. 2011) }\end{array}$ & $\begin{array}{l}\text { An adaptor protein with high } \\
\text { affinity to Arp3 by recruiting } \\
\text { Arp3 to the BTB }\end{array}$ & Not known \\
\hline Fascin1 & 54 & $\begin{array}{l}\text { Expressed at the BTB in all stages but } \\
\text { considerably diminished in stage VIII } \\
\text { (Gungor-Ordueri et al. 2014b) }\end{array}$ & Actin bundling & $\begin{array}{l}\text { Fascin } 1 \text { KO mice were viable and } \\
\text { fertile (Yamakita et al. 2009) }\end{array}$ \\
\hline Formin 1 & 180 & $\begin{array}{l}\text { Expressed at the BTB at stages I-VII, highly } \\
\text { expressed at stage VI, diminished at } \\
\text { stage VII, undetectable at stage VIII } \\
\text { (Li et al. 2015b) }\end{array}$ & $\begin{array}{l}\text { Induces actin polymerization } \\
\text { from the barbed } \\
\text { (fast-growing) end and } \\
\text { actin bundling }\end{array}$ & $\begin{array}{l}\text { Formin } 1 \mathrm{KO} \text { mice were viable and } \\
\quad \text { fertile (Zhou et al. 2009) }\end{array}$ \\
\hline Palladin & 95 & $\begin{array}{l}\text { Highly expressed at stages I-V, diminished } \\
\text { at stages VII-VIII (Qian et al. 2013b) }\end{array}$ & Actin bundling & $\begin{array}{l}\text { Palladin KO mice died around } \\
\text { E15.5 day (Luo et al. 2005) }\end{array}$ \\
\hline Plastin 3 & 70 & $\begin{array}{l}\text { Expressed in all stages but considerably } \\
\text { reduced at stage VIII (Li et al. 2015c) }\end{array}$ & Actin bundling & Not known \\
\hline Rai14 & 110 & $\begin{array}{l}\text { Expressed at the BTB in all stages but } \\
\text { considerably diminished at stages VI-VII } \\
\text { (Qian et al. 2013b) }\end{array}$ & $\begin{array}{l}\text { Actin binding, structurally } \\
\text { associated with palladin }\end{array}$ & Not known \\
\hline Vinculin & 130 & $\begin{array}{l}\text { Expressed at the BTB (Mulholland et al. } \\
\text { 2001) }\end{array}$ & $\begin{array}{l}\text { Adaptor protein, it has high } \\
\text { affinity to } \alpha \text {-actinin, an actin } \\
\text { cross-linking protein }\end{array}$ & $\begin{array}{l}\text { Vinculin KO mice could not survive } \\
\text { beyond E10 day (Xu et al. 1998) }\end{array}$ \\
\hline
\end{tabular}

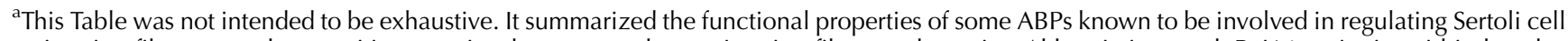
actin microfilaments or by recruiting proteins that can regulate actin microfilament dynamics. Abbreviation used: Rai14, retinoic acid-induced protein 14.

maturation arrest, disruption of fluid secretion by Sertoli cells leading to tubule atrophy, failure in spermatid transport, and an increase in cell apoptosis, thereby causing progressive germ cell exfoliation (for reviews, see Boekelheide et al. (2003) and Johnson (2014)). Other studies have also illustrated the disruption of actin microfilaments by cadmium and glycerol leads to TJ fibrils truncation, defragmentation of actin microfilaments, and BTB disruption, coinciding with germ cell exfoliation (Hew et al. 1993, Wiebe et al. 2000), since many of the adhesion protein complexes at the BTB utilize actin filaments for attachment (for a review, see Cheng \& Mruk (2002)). Interestingly, many of the toxicant-mediated defects in spermatogenesis are shared by other male contraceptive drugs under development such as adjudin which are known to exert their effects behind the BTB in the adluminal compartment (for a review, see Cheng (2014)). Studies performed in the past decade have shown that the actin-based cytoskeleton is also a target of toxicants (for a review, see Johnson

Table 2 Microtubule-associated proteins that regulate microtubule (MT) dynamics at the Sertoli cell BTB .

\begin{tabular}{|c|c|c|c|c|}
\hline MAP & $\begin{array}{l}\text { Mr in the } \\
\text { testis }(\mathrm{kDa})\end{array}$ & $\begin{array}{l}\text { Stage-specific expression } \\
\text { during the epithelial cycle }\end{array}$ & Function at the ВТВ & $\begin{array}{l}\text { Phenotype(s) } \\
\text { following KO in mice }\end{array}$ \\
\hline EB1 & 30 & $\begin{array}{l}\text { Expressed at the BTB in all } \\
\text { stages of the epithelial } \\
\text { cycle (Tang et al. 2015b) }\end{array}$ & $\begin{array}{l}\text { + TIP that binds to the fast }(+) \text {-growing end of } \\
\text { an MT, promotes MT assembly and links MT } \\
\text { ends to actin; it also serves as a regulator to } \\
\text { cross-talk with F-actin network, since EB1 } \\
\text { knockdown perturbs actin microfilament } \\
\text { organization at the Sertoli cell BTB } \\
\text { (Tang et al. } 2015 \mathrm{~b} \text { ) }\end{array}$ & Not known \\
\hline MARK4 & 79 & $\begin{array}{l}\text { Highly expressed at the BTB in } \\
\text { stages VI-IX (Tang et al. 2012) }\end{array}$ & $\begin{array}{l}\text { An Ser-/Thr-kinase, activates MAPs such as } \\
\text { Tau, involved in cell polarization }\end{array}$ & $\begin{array}{l}\text { MARK4 KO mice are } \\
\text { viable and fertile } \\
\text { (Sun et al. 2012) }\end{array}$ \\
\hline
\end{tabular}

${ }^{a}$ This Table was not intended to be exhaustive. It summarized the functional properties of some MT-associated proteins that regulate MT dynamics at the BTB. MAP, microtubule-associated protein. 
(2014)), in particular adjudin (for a review, see Cheng (2014)). Interestingly, the precise mechanism(s) by which cytoskeletons are disrupted following exposure of male rodents and/or humans to environmental toxicants remains largely unexplored until recent years. It is noted that actin microfilaments at the basal ES confer the adhesive strength of Sertoli cell-cell junctions at the BTB which also serve as the attachment site for adhesion protein complexes of the TJ (e.g., occludin-ZO-1), basal ES (e.g., N-cadherin- $\beta$-catenin), and G) (e.g., connexin 43) (for reviews, see Cheng \& Mruk (2002) and Mruk \& Cheng (2004)). Actin microfilaments, similar to MTs, are also polarized structures in mammalian cells including Sertoli cells in which the fast-growing end is called the barbed end and the slow-growing end is known as the pointed end (for reviews, see Pellegrin \& Mellor 2007, Schnittler et al. 2014). Studies have shown that actin dynamics are regulated by a number of ABPs, some of which, besides having affinity to bind to actin microfilaments, are regulatory proteins (Table 1 ).

On the other hand, MTs serve as the rails (or tracks) in Sertoli cells for germ cell transport (most notably spermatids), phagosome transport, as well as for intracellular transport involved in organelle positioning, cell shape, cell polarity, cell division, and endocytic vesicle-mediated trafficking (for reviews, see Vogl et al. (2008), Lie et al. (2010a), Tang et al. (2013, 2015a), O'Donnell (2014) and O'Donnell \& O'Bryan (2014)). MTs are also polarized structures in Sertoli cells with the fast-growing plus $(+)$ end and the slow-growing minus $(-)$ ends located near the basement membrane in the basal compartment and near the tubule lumen in the apical compartment respectively. MT dynamics are also regulated by a number of MT-binding proteins, yet few studies are found in the literature that investigate the role of these MT-binding proteins on MT dynamics in the testis (Table 2) (for reviews, see Tang et al. (2013, 2015a) and O'Donnell \& O'Bryan (2014)). Nonetheless, both cytoskeletal filaments undergo extensive re-organization involving polymerization (i.e., nucleation), depolymerization, stabilization, bundling, capping, branching, and severing/cleavage so that their configuration and/or organization can be rapidly altered in Sertoli cells in response to changes of the epithelial cycle, similar to other mammalian and non-mammalian cells (Lie et al. 2010a, O'Donnell et al. 2011, Zheng \& Iglesias 2013, O'Donnell 2014, O'Donnell \& O'Bryan 2014, Arous \& Halban 2015, Hausott \& Klimaschewski 2015, Tang et al. 2015a). Furthermore, studies have shown that the actin- and MT-based cytoskeletons are working in concert to modulate multiple mammalian cell functions including spermatogenesis in the testis (for reviews, see O'Donnell et al. (2011, 2014), Schappi et al. (2014), Coles \& Bradke (2015), Poulter \& Thomas (2015) and Tang et al. (2015a)). For instance, a recent report has shown that a knockdown of end-binding protein 1 ((EB1), a member of the growing plus $(+)$ end-tracking protein (+ TIP) (for reviews, see Akhmanova \& Steinmetz (2010) and Jiang \& Akhmanova (2011))), which is known to promote MT stabilization and to serve as an adaptor to recruit other + TIP proteins to the growing MT plus ends (Tamura \& Draviam 2012), not only affects the organization of MTs but also actin microfilaments in Sertoli cells (Tang et al. 2015b) (Table 2). In short, EB1 knockdown causes retraction of microtubules from cell cytosol including the cortical zone that support Sertoli cell-cell contacts to be closer to the cell nucleus, this in turn perturbs the Sertoli cell TJ-permeability function (Tang et al. 2015b). Interestingly, EB1 knockdown also causes defragmentation of actin microfilaments, leading to disorganization of actin filament bundles at the ES; this thus destabilizes adhesion proteins at the Sertoli cell TJ and basal ES including CAR, ZO-1, and N-cadherin, contributing to a failure of TJ barrier function (Tang et al. 2015b). Collectively, these findings support the notion that the actin and MT cytoskeletons are working in concert to support spermatogenesis, and that EB1 is likely to be one of the proteins which mediates the necessary cross-talk between the two cytoskeletons and to stabilize both MTs and actin microfilaments.

\section{Regulation of BTB actin-based cytoskeleton by ABPs and protein kinases}

\section{Introduction}

As briefly reviewed above, there are few published studies that examined the regulation of MT-based cytoskeleton except for katanin (a MT cleavage protein, its mutation leads to infertility in males by causing failure in spermiogenesis in mice and humans ( $\mathrm{O}^{\prime}$ Donnell et al. 2012, 2014, Smith et al. 2012)), microtubule affinityregulating kinase 4 (MARK4, a MT-stabilizing protein whose down-regulation induced by adjudin leads to spermatid exfoliation from the seminiferous epithelium in adult rats (Tang et al. 2012)), and EB1 (a+TIP that promotes plus end polymerization of MT (Tang et al. 2015b)). Since the involvement of MT in BTB function has recently been reviewed (for reviews, see O'Donnell (2014) and Tang et al. (2015a)), we focus our discussion on the actin-based cytoskeleton herein, since there are more recent published findings on this subject that have not been reviewed. We also provide a model herein (Fig. 2) which can serve as a helpful guide to investigators in the field.

\section{Actin binding proteins}

As noted above, the best studied ABPs in the testis that play crucial roles in BTB regulation are actin-bundling proteins (e.g., epidermal growth factor receptor pathway substrate 8 (Eps8), palladin, fascins, plastins, and ezrin) and branched actin nucleation proteins (e.g., actinrelated protein 2/3 (Arp2/3) and N-WASP) (Table 1). 
These two groups of proteins modulate the conversion of actin microfilaments between their bundled and unbundled/branched configuration, thereby conferring plasticity to the basal ES, which is necessary to facilitate the transport of preleptotene spermatocytes across the BTB. This rapid conversion of actin microfilaments between the bundled and unbundled/branched configuration also supports other intracellular trafficking events including the transport of organelles (e.g., transport of engulfed residual bodies by Sertoli cells near the tubule lumen at stage VIII of the cycle in the apical compartment to the basal compartment while transforming into phagosomes) and endocytic vesicle-mediated trafficking events involved in protein endocytosis, transcytosis, and recycling. In fact, the basal ES generates an ultrastructure known as the basal tubulobulbar complex, representing giant endocytic vesicles used for protein trafficking which can be readily detected by fluorescence or electron microscopy (Russell 1979, Xiao et al. 2014b) (for reviews, see Vogl et al. (2008, 2013)). As such, proteins at the degenerating 'old' BTB above preleptotene spermatocytes connected in clones (Weber \& Russell 1987) that are being transported across the barrier can be recycled to assemble the 'new' BTB behind these spermatocytes (Yan et al. 2008a, Smith \& Braun 2012) (for reviews see Mruk \& Cheng (2004) and Cheng \& Mruk (2010)) (Fig. 2). Thus, proteins at the BTB that serve as building blocks do not require continuous de novo synthesis throughout the epithelial cycle to avoid exhausting the limited metabolic resources and ability of the Sertoli cells. This is necessary, since each Sertoli cell is required to nurture $\sim 30-50$ germ cells at different stages of their development during the epithelial cycle (Weber et al. 1983).

\section{Actin-bundling proteins}

As noted above, ES is constituted conspicuously by an array of actin microfilament bundles found on both sides of the adjacent Sertoli cells near the basement membrane that support TJ and GJ to confer the barrier function of the BTB (Fig. 1). It is not unusual that these structures are maintained by actin-bundling proteins. Indeed, Eps8 (also an actin-barbed end-capping protein that reduces actin microfilament branching) (Lie et al. 2009a), palladin (Qian et al. 2013a), ezrin (GungorOrdueri et al. 2014a), plastin 3 (Li et al. 2015a), fascin 1 (Gungor-Ordueri et al. 2014b), and formin 1 (also an actin nucleation protein that promotes microfilament elongation besides conferring bundling of actin microfilaments) (Li et al. 2015b) recently have been shown to be actively involved in actin microfilament bundling in Sertoli cells (Table 1) and to confer Sertoli cell TJ-permeability barrier function, since their knockdown by $\mathrm{RNAi}$ is known to induce reorganization of actin microfilaments including defragmentation and disorganization. These changes thereby destabilize cell adhesion protein complexes at the BTB (e.g., occludin-ZO-1 and $\mathrm{N}$-cadherin- $\beta$-catenin), causing their re-distribution so that they no longer localize strictly near the cell surface to support cell adhesion but being internalized to the cell cytosol. The net result of these changes perturbs the Sertoli cell TJ barrier function. In this context, it is of interest to note that these changes involve an intriguing alteration on the spatiotemporal expression of several actin-bundling and branched actin-inducing proteins. For instance, a knockdown of plastin 3 by RNAi that causes unbundling and defragmentation of actin microfilaments across the Sertoli cell cytosol is the result of a down-regulation of actin-bundling/-barbed end-capping protein Eps8 and also actin-bundling protein palladin at the Sertoli cell-cell interface, which are coupled with an internalization of branched actin polymerization protein Arp3 (Li et al. 2015a). These findings thus illustrate that actin-bundling proteins are working in concert as a set of regulators to support actin microfilament bundles at the basal ES to confer BTB function, possibly via their spatiotemporal expression across different microdomains of the Sertoli cell, in particular at the site near the tunica propria. Studies in vivo also support the notion that these actin-bundling proteins are involved in conferring actin microfilament bundles in the seminiferous epithelium to support basal ES/BTB function. For instance, the expression of Eps8, plastin 3, fascin 1, and formin 1 is stage-specific, being highest in stages V-VII, but rapidly and considerably diminished in late stage VII through early stage VIII (Lie et al. 2009a, 2015a,b, Gungor-Ordueri et al. 2014b). This stage-specific downregulation of actin-bundling proteins thus support re-organization of the basal ES to facilitate BTB restructuring so that preleptotene spermatocytes can be transported across the BTB in stage VIII of the epithelial cycle (Fig. 2).

\section{Branched actin nucleation proteins}

The best studied branched actin polymerization protein in the mammalian tissues and cells is the Arp2/3 complex which when activated by N-WASP upstream, the complex induces barbed end nucleation, effectively converting actin microfilaments from a bundled to a branched configuration (for reviews, see Derivery \& Gautreau 2010, Cheng \& Mruk 2011) (Table 1). The Arp2/ 3 complex, when it is working in concert with bundling proteins such as palladin, Eps8, ezrin, and plastin, they confer plasticity to the actin-based cytoskeleton, necessary for cell motility, cell division, development, and also endocytic vesicle-mediated protein trafficking (for reviews, see Dawson et al. 2006, Blanchoin et al. 2014, Caceres et al. 2015, Coticchio et al. 2015). As depicted in Fig. 2, Arp3 has been shown to work in coordination with the actin-bundling proteins so that these two ABPs provide an effective mechanism to facilitate the transport of preleptotene spermatocytes. For instance, the 
considerable down-regulation of Eps8 (Lie et al. 2009a) and plastin 3 (Li et al. 2015a) at the basal ES/BTB to a level that is virtually non-detectable at stage VIII to facilitate the breakdown of actin microfilament bundles at the site is associated with a steady expression of Arp3 (Lie et al. $2010 b$ ); the net result thus favors endocytic vesiclemediated protein trafficking (for reviews, see Dawson et al. (2006) and Cheng \& Mruk (2010)) so that adhesion proteins from the 'old' BTB near the apical region of preleptotene spermatocytes can be endocytosed, transcytosed, and recycled to establish the 'new' BTB behind the germ cells (Yan et al. 2008a, Smith \& Braun 2012) (Fig. 2). Nonetheless, this hypothesis requires additional experiments to confirm in future studies. Furthermore, much work is needed to identify other crucial players to be involved in these cellular events.

\section{c-Src and c-Yes}

Studies have shown that Src family kinase (SFK) signaling (including c-Src and c-Yes) are involved in actin-based cytoskeletal dynamics in mammalian cells and tissues including the Sertoli cell BTB (for reviews, see Lavoie et al. (2010) and Xiao et al. (2012)). For instance, treatment of Sertoli cells with an established TJ-permeability barrier using SU6656 at $20 \mathrm{nM}$, a selective inhibitor of c-Yes with an IC50 at $20 \mathrm{nM}$ vs Src, Fyn, and Lyn (all are members of SFK family) at 280, 170, and $130 \mathrm{nM}$ respectively (Blake et al. 2000, Bowman et al. 2001), has been shown to cause defragmentation of actin microfilaments across the Sertoli cell cytosol and also retraction of F-actin from cell cortical zone to cell cytosol, but the presence of testosterone protects Sertoli cells from the disruptive effects of the c-Yes inhibitor (Xiao et al. 2011). These observations were subsequently confirmed by c-Yes specific knockdown by RNAi, since the silencing of $\mathrm{c}$-Yes by $\sim 70 \%$ indeed perturbed $\mathrm{F}$-actin organization in Sertoli cells, leading to actin microfilament defragmentation (Xiao et al. 2013). As such, $\mathrm{TJ}$ protein occludin and basal ES protein $\mathrm{N}$-cadherin no longer tightly associate with the BTB, leading to BTB disruption based on an in vivo study (Xiao et al. 2013). Studies using biochemical assays and knockdown of c-Yes or c-Src using specific siRNA duplexes vs nontargeting negative control duplexes to monitor protein endocytosis, recycling, and degradation, c-Yes has been shown to promote endocytosed integral membrane proteins (e.g., JAM-A and CAR) to the pathway of transcytosis and recycling, whereas c-Src promotes intracellular degradation of endocytosed proteins at the Sertoli cell BTB (Xiao et al. 2014b). Collectively, these findings illustrate that $\mathrm{c}-\mathrm{Src}$ and $\mathrm{c}-\mathrm{Yes}$ are working in concert to modulate F-actin organization at the Sertoli cell BTB, in particular their role in endocytic vesiclemediated protein trafficking to determine the fate of endocytosed proteins differentially as depicted in a working model in Fig. 2.

\section{Focal adhesion kinase}

Studies in vitro (Lie et al. 2012) and in vivo (Wan et al. 2013) based on the use of phosphomimetic vs nonphosphorylatable mutants have shown that the two phosphorylated (activated) forms of focal adhesion kinase (FAK), namely, p-FAK-Tyr ${ }^{407}$ and p-FAK-Tyr ${ }^{397}$, are crucial regulators of ES including the basal ES/BTB and the apical ES in the rat testis (for reviews, see Wan et al. (2014) and Xiao et al. (2014a)). For instance, p-FAK-Tyr ${ }^{407}$ is highly expressed at the basal ES/BTB in the testis based on studies using dual-labeled immunofluorescence analysis and confocal microscopy (Lie et al. 2012). p-FAK-Tyr ${ }^{407}$ also modulates the intrinsic branched actin nucleation activity of the Arp2/3 complex in Sertoli cells cultured in vitro with an established functional TJ barrier (Lie et al. 2012), illustrating that p-FAK-Tyr ${ }^{407}$ is involved in actin microfilament organization at the ES. Indeed, consistent with these findings, Sertoli cell-specific deletion of $\mathrm{N}$-WASP in the mouse testis, the upstream activator of the Arp2/3 complex, also leads to male infertility (Rotkopf et al. 2011), due to a failure in spermiogenesis and a permanent BTB disruption (Xiao et al. 2014C), possibly the result of a loss of plasticity of the F-actin network to be able to convert between bundled and unbundled/branched configuration. Also, a loss of the ability of Sertoli cells in the seminiferous epithelium to re-organize actin microfilaments following N-WASP Sertoli cell-specific knockout $(K O)$ in mice also leads to a considerable reduction of $\mathrm{p}$-FAK-Tyr ${ }^{438}$ (which corresponds to p-FAK-Tyr ${ }^{407}$ in the rat testis), since the disorganized F-actin network at the BTB fails to support proper spatiotemporal expression of p-FAK-Tyr ${ }^{438}$ to confer BTB function (Xiao et al. 2014c). Collectively, these findings thus illustrate an intimate functional relationship between F-actin organization and p-FAK$\mathrm{Tyr}^{407}$. In fact, Arp3 may be a putative substrate of p-FAK-Tyr ${ }^{407}$ in the rat testis, which should be carefully evaluated in future studies. Figure 2 also depicts the likely involvement of p-FAK-Tyr ${ }^{407}$ in regulating actin microfilament organization at the Sertoli cell BTB in the rat testis.

\section{Regulation of the BTB via the apical ES-BTB- basement membrane axis}

Earlier studies have shown that the events of spermiation and BTB remodeling that occur at the opposite ends of the seminiferous epithelium at stage VIII of the epithelial cycle are coordinated via a local functional axis known as the apical ES-BTB-basement membrane axis (Yan et al. 2008b). In short, fragments of laminin chains are generated at the apical ES during its degeneration to facilitate the release of sperm at spermiation, possibly mediated by MMP2 cleavage (Siu \& Cheng 2004). These fragments have been shown to possess potent biological 
activity to induce BTB restructuring by perturbing the Sertoli cell TJ-permeability barrier function (Yan et al. 2008b). Subsequent studies have identified the biologically active domain in one of these fragments designated F5 peptide, which is capable of perturbing the Sertoli cell TJ barrier in studies both in vitro and in vivo (Su et al. 2012), illustrating the physiological significance of this axis in regulating BTB function during spermatogenesis. The model depicted in Fig. 2 illustrates the likely role of these biologically active fragments in coordinating the events of BTB restructuring to facilitate the transport of preleptotene spermatocytes at stage VIII of the epithelial cycle. Since this topic has recently been reviewed (Cheng \& Mruk 2010), we thus only briefly summarize these findings herein. On the other hand, a recent report from our laboratory has demonstrated a biologically active fragment released from collagen chains in the basement membrane, such as the non-collagenous 1 (NC1) domain, which is also a potent regulator to modulate BTB function (Wong \& Cheng 2013), illustrating a functional link between the BTB and the basement membrane. Much work is needed to understand the role and the biology of biologically active laminin chains generated at the apical ES, and NC1 domain released from collagens in the basement membrane, to modulate basal ES/BTB function in the testis.

\section{Future perspectives and concluding remarks}

As briefly discussed herein, the BTB in the mammalian testis is regulated by cytoskeletons. There is accumulating evidence that MT-based cytoskeleton is also involved. For instance, the knockdown of EB1(a MT+TIP) that is known to stabilize MTs in Sertoli cells has been shown to perturb the Sertoli cell TJ barrier function by disorganizing MT configuration, in which MTs no longer stretch across the Sertoli cell cytosol but retract closer to the cell nuclei (Tang et al. 2015b). Furthermore, actin microfilament defragmentation and disorganization are also noted in Sertoli cells following EB1 knockdown, which are mediated by changes in the spatiotemporal expression of Arp3 in which Arp3 is considerably expressed in cell cytosol, closer to the cell nucleus instead of at the cortical zone as in control Sertoli cell epithelium (Tang et al. 2015b). Thus, F-actin microfilaments no longer assume a conspicuous bundled configuration that stretch across the entire Sertoli cell following EB1 knockdown (Tang et al. 2015b), illustrating EB1 can also modulate actin microfilament organization. There is mounting evidence in the literature to suggest that some of the MT or actin microfilament regulatory proteins modulate both cytoskeletons such as in neurons (for a review, see Coles \& Bradke (2015)). For instance, formin 1, a barbed end actin nucleation protein that promotes actin polymerization to form long stretches of actin microfilaments that plays a critical role in ES dynamics including the basal ES/BTB in the rat testis ( $\mathrm{Li}$ et al. 2015b), is also an emerging $A B P$ that regulates MT dynamics (for a review, see Chesarone et al. (2010)). The model depicted in Fig. 2 illustrates the likely interactions between different classes of regulatory proteins (e.g., actin-bundling proteins, branched actin polymerization proteins, and non-receptor protein kinases) to modulate cytoskeletal functions at the basal ES/BTB to regulate the transport of preleptotene spermatocytes across the barrier. It is obvious that these proteins (Tables 1 and 2) can now be investigated as a whole to better understand the precise mechanism(s) by which each class of these proteins is interacting with the other to modulate junction remodeling at the BTB. There are many questions that remain unanswered. For instance: What is the precise mechanism through which FAK, C-Src, and c-Yes interact with one another to modulate ABPs and other MT binding proteins? Is this mediated by protein phosphorylation to unleash the intrinsic activities of these ABPs, such as bundling activity of palladin? Are these events regulated by cytokines and/or testosterone or other biomolecules? How do Sertoli cells across the seminiferous epithelium coordinate with one another during the epithelial cycle to modulate their cytoskeletal organization? Is this mediated by intercellular bridges? If it is, what are the biomolecules that trigger this coordination? It is likely that many of these questions will be answered in the next few years, which will provide a better picture regarding the functional regulation of the BTB to support spermatogenesis.

\section{Declaration of interest}

The authors declare that there is no conflict of interest that could be perceived as prejudicing the impartiality of the review.

\section{Funding}

This work was supported by grants from the National Institutes of Health (R01 HD056034 to C Y Cheng and U54 HD029990, Project 5 to $C$ Y Cheng).

\section{References}

Akhmanova A \& Steinmetz MO 2010 Microtubule + TIPs at a glance. Journal of Cell Science 123 3415-3419. (doi:10.1242/jcs.062414)

Amory JK, Muller CH, Shimshoni JA, Isoherranen N, Paik J, Moreb JS, Amory DW, Evanoff R, Goldstein AS \& Griswold MD 2011 Suppression of spermatogenesis by bisdichloroacetyldiamines is mediated by inhibition of testicular retinoic acid biosynthesis. Journal of Andrology 32 111-119. (doi:10.2164/jandrol.110.010751)

Arous C \& Halban PA 2015 The skeleton in the closet: actin cytoskeletal remodeling in $\beta$-cell function. American Journal of Physiology. Endocrinology and Metabolism 309 E611-E620. (doi:10.1152/ajpendo. 00268.2015)

Bartles JR, Wierda A \& Zheng L 1996 Identification and characterization of espin, an actin-binding protein localized to the F-actin-rich junctional plaques of Sertoli cell ectoplasmic specializations. Journal of Cell Science 109 1229-1239. 
Blake RA, Broome MA, Liu X, Wu J, Gishizky M, Sun L \& Courtneidge SA 2000 SU6656, a selective Src family kinase inhibitor, used to probe growth factor signaling. Molecular and Cell Biology 20 9018-9027. (doi:10.1128/MCB.20.23.9018-9027.2000)

Blanchoin L, Boujemaa-Paterski R, Sykes C \& Plastino J 2014 Actin dynamics, architecture, and mechanics in cell motility. Physiological Reviews 94 235-263. (doi:10.1152/physrev.00018.2013)

Boekelheide K, Fleming SL, Allio T, Embree-ku ME, Hall SJ, Johnson KJ, Kwon EJ, Patel SR, Rasoulpour RJ, Schoenfeld HA et al. 2003 2,5-hexanedione-induced testicular injury. Annual Review of Pharmacology and Toxicology 43 125-147. (doi:10.1146/annurev.pharmtox.43. 100901.135930)

Bowman T, Broome MA, Sinibaldi D, Wharton W, Pledger WJ, Sedivy JM, Irby R, Yeatman T, Courtneidge SA \& Jove R 2001 Stat3-mediated Myc expression is required for Src transformation and PDFG-induced mitogenesis. PNAS 98 7319-7324. (doi:10.1073/pnas.131568898)

Caceres R, Abou-Ghali M \& Plastino J 2015 Reconstituting the actin cytoskeleton at or near surfaces in vitro. Biochimica et Biophysica Acta 1853 3006-3014. (doi:10.1016/j.bbamcr.2015.07.021)

Campbell M \& Humphries P 2012 The blood-retina barrier: tight junctions and barrier modulation. Advances in Experimental Medicine and Biology $76370-84$.

Cheng CY 2014 Toxicants target cell junctions in the testis - insights from the indazole-carboxylic acid model. Spermatogenesis 4 e981485. (doi:10.4161/21565562.2014.981485)

Cheng CY \& Mruk DD 2002 Cell junction dynamics in the testis: Sertoligerm cell interactions and male contraceptive development. Physiological Reviews 82 825-874. (doi:10.1152/physrev.00009.2002)

Cheng CY \& Mruk DD 2010 A local autocrine axis in the testes that regulates spermatogenesis. Nature Reviews. Endocrinology 6 380-395. (doi:10.1038/nrendo.2010.71)

Cheng CY \& Mruk DD 2011 Regulation of spermiogenesis, spermiation and blood-testis barrier dynamics: novel insights from studies on Eps8 and Arp3. Biochemical Journal 435 553-562. (doi:10.1042/ BJ20102121)

Cheng CY \& Mruk DD 2012 The blood-testis barrier and its implication in male contraception. Pharmacological Review 64 16-64. (doi:10.1124/ pr.110.002790)

Cheng CY, Gunsalus GL, Morris ID, Turner TT \& Bardin CW 1986 The heterogeneity of rat androgen binding protein (rABP) in the vascular compartment differs from that in the testicular tubular lumen: further evidence for bidirectional secretion of rABP. Journal of Andrology 7 175-179. (doi:10.1002/j.1939-4640.1986.tb00906.x)

Cheng CY, Mruk DD, Silvestrini B, Bonanomi M, Wong CH, Siu MK, Lee NP \& Mo MY 2005 AF-2364 [1-(2,4-dichlorobenzyl)-1H-indazole-3-carbohydrazidel is a potential male contraceptive: a review of recent data. Contraception 72 251-261. (doi:10.1016/j.contraception.2005.03.008)

Cheng YH, Wong EW \& Cheng CY 2011 Cancer/testis (CT) antigens, carcinogenesis and spermatogenesis. Spermatogenesis 1 209-220. (doi:10.4161/spmg.1.3.17990)

Chesarone MA, DuPage AG \& Goode BL 2010 Unleashing formins to remodel the actin and microtubule cytoskeletons. Nature Reviews. Molecular Cell Biology 11 62-74. (doi:10.1038/nrm2816)

Chung SS, Wang X, Roberts SS, Griffey SM, Reczek PR \& Wolgemuth DJ 2011 Oral administration of a retinoic acid receptor antagonist reversibly inhibits spermatogenesis in mice. Endocrinology 152 2492-2502. (doi:10.1210/en.2010-0941)

Clermont Y 1972 Kinetics of spermatogenesis in mammals: seminiferous epithelium cycle and spermatogonial renewal. Physiological Reviews 52 198-235.

Coles CH \& Bradke F 2015 Coordinating Neuronal Actin-Microtubule Dynamics. Current Biology 25 R677-R691. (doi:10.1016/j.cub.2015. 06.020)

Coticchio G, Dal Canto M, Mignini Renzini M, Guglielmo MC, Brambillasca F, Turchi D, Novara PV \& Fadini R 2015 Oocyte maturation: gamete-somatic cells interactions, meiotic resumption, cytoskeletal dynamics and cytoplasmic reorganization. Human Reprodction Update 21 427-454. (doi:10.1093/humupd/dmv011)

Dawson JC, Legg JA \& Machesky LM 2006 Bar domain proteins: a role in tubulation, scission and actin assembly in clathrin-mediated endocytosis. Trends in Cell Biology 16 493-498. (doi:10.1016/j.tcb.2006. 08.004)
Derivery E \& Gautreau A 2010 Generation of branched actin networks: assembly and regulation of the N-WASP and WAVE molecular machines. BioEssays 32 119-131. (doi:10.1002/bies.200900123)

Dufour JM, Gores P, Hemendinger R, Emerich DF \& Halberstadt CR 2004 Transgenic Sertoli cells as a vehicle for gene therapy. Cell Transplantation 13 1-6. (doi:10.3727/000000004772664833)

Dufour JM, Dass B, Halley KR, Korbutt GS, Dixon DE \& Rajotte RV 2008 Sertoli cell line lacks the immunoprotective properties associated with primary Sertoli cells. Cell Transplantation 17 525-534. (doi:10.3727/ 096368908785096033)

Easton AS 2012 Regulation of permeability across the blood-brain barrier. Advances in Experimental Medicine and Biology 763 1-19.

Fawcett D 1975. Utrastructure and function of the Sertoli cell. In Handbook of Physiology, pp. 21-25. Eds D Hamilton \& R Greep. Washington, DC: American Physiological Society.

Fawcett DW, Leak LV \& Heidger PM 1970 Electron microscopic observations on the structural components of the blood-testis barrier. Journal of Reproduction \& Fertility 10 105-122.

Franca LR, Auharek SA, Hess RA, Dufour JM \& Hinton BT 2012 Bloodtissue barriers: morphofunctional and immunological aspects of the blood-testis and blood-epididymal barriers. Advances in Experimental Medicine and Biology 763 237-259.

Grima J, Silvestrini B \& Cheng CY 2001 Reversible inhibition of spermatogenesis in rats using a new male contraceptive, 1-(2,4dichlorobenzyl)-indazole-3-carbohydrazide. Biological Reproduction 64 1500-1508. (doi:10.1095/biolreprod64.5.1500)

Gungor-Ordueri NE, Tang El, Celik-Ozenci C \& Cheng CY 2014a Ezrin is an actin binding protein that regulates Sertoli cell and spermatid adhesion during spermatogenesis. Endocrinology 155 3981-3995. (doi:10.1210/ en.2014-1163)

Gungor-Ordueri NE, Celik-Ozenci C \& Cheng CY 2014b Fascin 1 is an actin filament-bundling protein that regulates ectoplasmic specialization dynamics in the rat testis. American Journal of Physiology. Endocrinology and Metabolism 307 E738-E753. (doi:10.1152/ajpendo.00113.2014)

Hausott B \& Klimaschewski L 2015 Membrane turnover and receptor trafficking in regenerating axons. European Journal of Neuroscience. In press. (doi:10.1111/ejn.13025)

Hess RA \& de Franca LR 2008 Spermatogenesis and cycle of the seminiferous epithelium. Advances in Experimental Medicine and Biology 636 1-15.

Hew KW, Heath GL, Jiwa AH \& Welsh MJ 1993 Cadmium in vivo causes disruption of tight junction-associated microfilaments in rat Sertoli cells. Biological Reproduction 49 840-849. (doi:10.1095/biolreprod49.4.840)

Hild SA, Reel JR, Larner JM \& Blye RP 2001 Disruption of spermatogenesis and Sertoli cell structure and function by the indenopyridine CDB-4022 in rats. Biological Reproduction 65 1771-1779. (doi:10.1095/biolreprod65. 6.1771)

Hild SA, Marshall GR, Attardi BJ, Hess RA, Schlatt S, Simorangkir DR, Ramaswamy S, Koduri S, Reel JR \& Plant TM 2007 Development of I-CDB-4022 as a nonsteroidal male oral contraceptive: induction and recovery from severe oligospermia in the adult male cynomolgus monkey (Macaca fascicularis). Endocrinology 148 1784-1796. (doi:10.1210/en.2006-1487)

Jiang K \& Akhmanova A 2011 Microtubule tip-interacting proteins: a view from both ends. Current Opinion in Cell Biology 23 94-101. (doi:10.1016/j.ceb.2010.08.008)

Johnson KJ 2014 Testicular histopathology associated with disruption of the Sertoli cell cytoskeleton. Spermatogenesis 4 e979106. (doi:10.4161/ 21565562.2014.979106)

Kaur G, Mital P \& Dufour JM 2013 Testis immune privilege - assumptions versus facts. Animal Reproduction 10 3-15.

Kaur G, Thompson LA \& Dufour JM 2014 Sertoli cells - immunological sentinels of spermatogenesis. Seminar in Cellular, Molecular and Developmental Biology 30 36-44. (doi:10.1016/j.semcdb.2014.02.011)

Lavoie JN, Landry MC, Faure RL \& Champagne C 2010 Src-family kinase signaling, actin-mediated membrane trafficking and organellar dynamics in the control of cell fate: lessons to be learned from the adenovirus E4orf4 death factor. Cell Signalling 22 1604-1614. (doi:10.1016/j. cellsig.2010.04.007)

Li MW, Xiao X, Mruk DD, Lam YL, Lee WM, Lui WY, Bonanomi M, Silvestrini B \& Cheng CY 2011 Actin-binding protein drebrin E is involved in junction dynamics during spermatogenesis. Spermatogenesis 1 123-136. (doi:10.4161/spmg.1.2.16393) 
Li N, Mruk DD, Wong CK, Lee WM, Han D \& Cheng CY 2015a Actinbundling protein plastin 3 is a regulator of ectoplasmic specialization dynamics during spermatogenesis in the rat testis. FASEB Journal 29 3788-3805. (doi:10.1096/fj.14-267997)

Li N, Mruk DD, Wong CK, Han D, Lee WM \& Cheng CY 2015b Formin 1 regulates ectoplamic specialization in the rat testis through its actin nucleation and bundling activity. Endocrinology 156 2969-2983. (doi:10.1210/en.2015-1161)

Li N, Mruk DD, Wong CK, Lee WM, Han D \& Cheng CY 2015c Actin bundling protein plastin 3 is a regulator of ectoplasmic specialization (ES) dynamics during spermatogenesis in the rat testis. FASEB Journal 29 3788-3805. (doi:10.1096/fj.14-267997)

Lie PP, Mruk DD, Lee WM \& Cheng CY 2009a Epidermal growth factor receptor pathway substrate 8 (Eps8) is a novel regulator of cell adhesion and the blood-testis barrier integrity in the seminiferous epithelium. FASEB Journal 23 2555-2567. (doi:10.1096/fj.06-070573)

Lie PP, Mruk DD, Lee WM \& Cheng CY 2009b Epidermal growth factor receptor pathway substrate 8 (Eps8) is a novel regulator of cell adhesion and the blood-testis barrier integrity in the seminiferous epithelium. FASEB Journal 23 2555-2567. (doi:10.1096/fj.06-070573)

Lie PP, Mruk DD, Lee WM \& Cheng CY 2010a Cytoskeletal dynamics and spermatogenesis. Philosophical Transactions of the Royal Society of London. Series A 365 1581-1592. (doi:10.1098/rstb.2009.0261)

Lie PP, Chan AY, Mruk DD, Lee WM \& Cheng CY 2010b Restricted Arp3 expression in the testis prevents blood-testis barrier disruption during junction restructuring at spermatogenesis. PNAS 107 11411-11416. (doi:10.1073/pnas.1001823107)

Lie PP, Mruk DD, Mok KW, Su L, Lee WM \& Cheng CY 2012 Focal adhesion kinase- $\mathrm{Tyr}^{407}$ and $-\mathrm{Tyr}^{397}$ exhibit antagonistic effects on blood-testis barrier dynamics in the rat. PNAS 109 12562-12567. (doi:10.1073/pnas. 1202316109)

Luca G, Calvitti M, Mancuso F, Falabella G, Arato I, Bellucci C, List EO, Bellezza E, Angeli G, Lilli C et al. 2013 Reversal of experimental Laron syndrome by xenotransplantation of microencapsulated porcine Sertoli cells. Journal of Controlled Release 165 75-81. (doi:10.1016/j.jconrel. 2012.08.028)

Luca G, Mancuso F, Calvitti M, Arato I, Falabella G, Bufalari A, De Monte V, Tresoldi E, Nastruzzi C, Basta G et al. 2015 Long-term stability, functional competence, and safety of microencapsulated specific pathogen-free neonatal porcine Sertoli cells: a potential product for cell transplant therapy. Xenotransplantation 22 273-283. (doi:10.1111/ xen.12175)

Luo H, Liu X, Wang F, Huang Q, Shen S, Wang L, Xu G, Sun X, Kong H, Gu M et al. 2005 Disruption of palladin results in neural tube closure defects in mice. Molecular and Cellular Neurosciences 29 507-515. (doi:10.1016/j.mcn.2004.12.002)

Meinhardt A \& Hedger MP 2011 Immunological, paracrine and endocrine aspects of testicular immune privilege. Molecular and Cellular Endocrinology 335 60-68. (doi:10.1016/j.mce.2010.03.022)

Mital P, Kaur G \& Dufour JM 2010 Immunoprotective Sertoli cells: making allogeneic and xenogeneic transplantation feasible. Reproduction 139 495-504. (doi:10.1530/REP-09-0384)

Mital P, Hinton BT \& Dufour JM 2011 The blood-testis and bloodepididymis barriers are more than just their tight junctions. Biological Reproduction 84 851-858. (doi:10.1095/biolreprod.110. 087452)

Mok KW, Mruk DD, Lee WM \& Cheng CY 2012 Spermatogonial stem cells alone are not sufficient to re-initiate spermatogenesis in the rat testis following adjudin-induced infertility. International Journal of Andrology 35 86-101. (doi:10.1111/j.1365-2605.2011.01183.x)

Mruk DD \& Cheng CY 2004 Sertoli-Sertoli and Sertoli-germ cell interactions and their significance in germ cell movement in the seminiferous epithelium during spermatogenesis. Endocrinology Reviews 25 747-806. (doi:10.1210/er.2003-0022)

Mruk DD \& Cheng CY 2015 The mammalian blood-testis barrier: its biology and regulation. Endocrinology Reviews 36 564-591. (doi:10.1210/er.2014-1101)

Mruk DD, Su L \& Cheng CY 2011 Emerging role for drug transporters at the blood-testis barrier. Trends in Pharmacological Sciences 32 99-106. (doi:10.1016/j.tips.2010.11.007)
Mulholland DJ, Dedhar S \& Vogl AW 2001 Rat seminiferous epithelium contains a unique junction (Ectoplasmic specialization) with signaling properties both of cell/cell and cell/matrix junctions. Biological Reproduction 64 396-407. (doi:10.1095/biolreprod64.1.396)

O'Bryan MK \& Hedger MP 2008 Inflammatory networks in the control of spermatogenesis: chronic inflammation in an immunologically privileged tissues? Advances in Experimental Medicine and Biology 636 92-114.

O'Donnell L 2014 Mechanisms of spermiogenesis and spermiation and how they are disturbed. Spermatogenesis 4 e979623. (doi:10.4161/ 21565562.2014.979623)

O'Donnell L \& O'Bryan MK 2014 Microtubules and spermatogenesis. Seminars in Cell \& Developmental Biology 30 45-54. (doi:10.1016/j. semcdb.2014.01.003)

O'Donnell L, Nicholls PK, O'Bryan MK, McLachlan RI \& Stanton PG 2011 Spermiation: the process of sperm release. Spermatogenesis 1 14-35. (doi:10.4161/spmg.1.1.14525)

O'Donnell L, Rhodes D, Smith SJ, Merriner DJ, Clark BJ, Borg C, Whittle B, O'Connor AE, Smith LB, McNally FJ et al. 2012 An essential role for katanin p80 and microtubule severing in male gamete production. PLoS Genetics 8 e1002698. (doi:10.1371/journal.pgen. 1002698)

O'Donnell L, McLachlan RI, Merriner DJ, O'Bryan MK \& Jamsai D 2014 KATNB1 in the human testis and its genetic variants in fertile and oligoasthenoteratozoospermic infertile men. Andrology 2 884-891. (doi:10.1111/andr.276)

Parvinen M 1982 Regulation of the seminiferous epithelium. Endocrinology Reviews 3 404-417. (doi:10.1210/edrv-3-4-404)

Pellegrin S \& Mellor H 2007 Actin stress fibers. Journal of Cell Science 120 3491-3499. (doi:10.1242/jcs.018473)

Pelletier RM 2011 The blood-testis barrier: the junctional permeability, the proteins and the lipids. Progress in Histochemistry and Cytochemistry 46 49-127. (doi:10.1016/j.proghi.2011.05.001)

Poulter NS \& Thomas SG 2015 Cytoskeletal regulation of platelet formation: coordination of $\mathrm{F}$-actin and microtubules. International Journal of Biochemistry \& Cell Biology 66 69-74. (doi:10.1016/j.biocel.2015. 07.008)

Qian X, Mruk DD, wong EW, Lie PP \& Cheng CY 2013a Palladin is a regulator of actin filament bundles at the ectoplasmic specialization in the rat testis. Endocrinology 154 1907-1920. (doi:10.1210/en.20122269)

Qian X, Mruk DD \& Cheng CY 2013b Rai14 (retinoic acid induced protein 14) is involved in regulating f-actin dynamics at the ectoplasmic specialization in the rat testis*. PLOS ONE 8 e60656. (doi:10.1371/ journal.pone.0060656)

Revenu C, Ubelmann F, Hurbain I, El-Marjou F, Dingli F, Loew D, Delacour D, Gilet J, Brot-Laroche E, Rivero F et al. 2012 A new role for the architecture of microvillar actin bundles in apical retention of membrane proteins. Molecular Biology of the Cell 23 324-336. (doi:10.1091/mbc.E11-09-0765)

Rotkopf S, Hamberg Y, Aigaki T, Snapper SB, Shilo BZ \& Shejter ED 2011 The WASp-based actin polymerization machinery is required in somatic support cells for spermatid maturation and release. Development 138 2729-2739. (doi:10.1242/dev.059865)

Russell LD 1977a Movement of spermatocytes from the basal to the adluminal compartment of the rat testis. American Journal of Anatomy 148 313-328. (doi:10.1002/aja.1001480303)

Russell LD 1977b Observations on rat Sertoli ectoplasmic ('junctional') specializations in their association with germ cells of the rat testis. Tissue \& Cell 9 475-498. (doi:10.1016/0040-8166(77)90007-6)

Russell LD 1978 The blood-testis barrier and its formation relative to spermatocyte maturation in the adult rat: a lanthanum tracer study. Anatamoical Record 190 99-112. (doi:10.1002/ar.1091900109)

Russell LD 1979 Observations on the inter-relationships of Sertoli cells at the level of the blood-testis barrier: evidence for formation and resorption of Sertoli-Sertoli tubulobulbar complexes during the spermatogenic cycle of the rat. American Journal of Anatomy $\mathbf{1 5 5}$ 259-279. (doi:10.1002/aja.1001550208)

Russell LD, Malone JP \& MacCurdy DS 1981 Effect of the microtubule disrupting agents, colchicine and vinblastine, on seminiferous tubule structure in the rat. Tissue \& Cell 13 349-367. (doi:10.1016/00408166(81)90010-0) 
Russell LD, Goh JC, Rashed RM \& Vogl AW 1988 The consequences of actin disruption at Sertoli ectoplasmic specialization sites facing spermatids after in vivo exposure of rat testis to cytochalasin D. Biological Reproduction 39 105-118. (doi:10.1095/biolreprod39.1.105)

Saotome I, Curto M \& McClatchey Al 2004 Ezrin is essential for epithelial organization and villus morphogenesis in the developing intestine. Developmental Cell 6 855-864. (doi:10.1016/j.devcel.2004.05.007)

Schappi JM, Krbanjevic A \& Rasenick MM 2014 Tubulin, actin and heterotrimeric G proteins: coordination of signaling and structure. Biochimica et Biophysica Acta 1838 674-681. (doi:10.1016/j.bbamem.2013.08.026)

Schnittler H, Taha M, Schnittler MO, Taha AA, Lindemann N \& Seebach J 2014 Actin filament dynamics and endothelial cell junctions: the Ying and Yang between stabilization and motion. Cell Tissue Research 355 529-543. (doi:10.1007/s00441-014-1856-2)

Scita G, Nordstrom J, Carbone R, Tenca P, Giardina G, Gutkind S, Bjarnegard M, Betsholtz C \& Di Fiore PP 1999 EPS8 and E3B1 transduce signals from Ras to Rac. Nature 401 290-293. (doi:10.1038/45822)

Setchell B 1980 The functional significance of the blood-testis barrier. Journal of Andrology 13-10. (doi:10.1002/j.1939-4640.1980.tb00003.x)

Setchell BP 2008 Blood-testis barrier, functional and transport proteins and spermatogenesis. Advances in Experimental Medicine and Biology 636 212-233.

Setchell BP \& Waites GM 1970 Changes in the permeability of the testicular capillaries and of the "blood-testis barrier" after injection of cadmium chloride in the rat. Journal of Endocrinology 47 81-86. (doi:10.1677/joe. $0.0470081)$

Setchell BP \& Waites GMB 1975 The blood-testis barrier. In The Handbook of Physiology. Section 7, Vol. V. Male Reproductive System, pp. 143-172. eds DW Hamilton \& RO Greep. Washington, DC: American Physiological Society.

Simpson AJ, Caballero OL, Jungbluth A, Chen YT \& Old LJ 2005 Cancer/testis antigens, gametogenesis and cancer. Nature Reviews. Cancer 5 615-625. (doi:10.1038/nrc1669)

Siu MK \& Cheng CY 2004 Interactions of proteases, protease inhibitors, and the $\beta 1$ integrin/laminin Y3 protein complex in the regulation of ectoplasmic specialization dynamics in the rat testis. Biological Reproduction 70 945-964. (doi:10.1095/biolreprod.103.023606)

Smith BE \& Braun RE 2012 Germ cell migration across Sertoli cell tight junctions. Science 338 798-802. (doi:10.1126/science.1219969)

Smith LB, Milne L, Nelson N, Eddie S, Brown P, Atanassova N, O'Bryan MK, O'Donnell L, Rhodes D, Wells S et al. 2012 KATNAL1 regulation of Sertoli cell microtubule dynamics is essential for spermiogenesis and male fertility. PLoS Genetics 8 e1002697. (doi:10.1371/journal.pgen. 1002697)

Su L, Mruk DD, Lie PP, Silvestrini B \& Cheng CY 2012 A peptide derived from laminin-g3 reversibly impairs spermatogenesis in rats. Nature Communications 3 1185. (doi:10.1038/ncomms2171)

Sun C, Tian L, Nie J, Zhang H, Han X \& Shi Y 2012 Inactivation of MARK4, an AMP-activated protein kinase (AMPK)-related kinase, leads to insulin hypersensitivity and resistance to diet-induced obesity. Journal of Biolgical Chemistry 287 38305-38315. (doi:10.1074/jbc. M112.388934)

Tamura N \& Draviam VM 2012 Microtubule plus-ends within a mitotic cell are 'moving platforms' with anchoring, signalling and force-coupling roles. Open Biology 2 12013. (doi:10.1098/rsob.120132)

Tamura A, Kikuchi S, Hata M, Katsuno T, Matsui T, Hayashi H, Suzuki Y, Noda T \& Tsukita S 2005 Achlorhydria by ezrin knockdown: defects in the formation/expansion of apical canaliculi in gastric parietal cells. Journal of Cell Biology 169 21-28. (doi:10.1083/jcb.200410083)

Tang EI, Xiao X, Mruk DD, Qian XJ, Mok KW, Jenardhanan P, Lee WM, Mathur PP \& Cheng CY 2012 Microtubule affinity-regulating kinase 4 (MARK4) is a component of the ectoplasmic specialization in the rat testis. Spermatogenesis 2 117-126. (doi:10.4161/spmg.20724)

Tang EI, Mruk DD \& Cheng CY 2013 MAP/microtubule affinity-regulating kinases, microtubule dynamics, and spermatogenesis. Journal of Endocrinology 217 R13-R23. (doi:10.1530/JOE-12-0586)

Tang EI, Mruk DD, Lee WM \& Cheng CY 2015a Cell-cell interactions, cell polarity, and the blood-testis barrier. In Cell Polarity 1, pp. 303-326, Ed. K Ebnet. Geneva: Springer International Publishing. (doi:10.1007/978-3319-14463-4_13)
Tang EI, Mok KW, Lee WM \& Cheng CY 2015b EB1 regulates tubulin and actin cytoskeletal networks at the Sertoli cell blood-testis barrier in male rats - an in vitro study. Endocrinology 156 680-693. (doi:10.1210/en. 2014-1720)

Tash JS, Attardi B, Hild SA, Chakrasali R, Jakkaraj SR \& Georg GI 2008 A novel potent indazole carboxylic acid derivative blocks spermatogenesis and is contraceptive in rats after a single oral dose. Biological Reproduction 78 1127-1138. (doi:10.1095/biolreprod.106. 057810)

Turner TT, Jones CC, Howards SS, Ewing LL, Zegeye B \& Gunsalus GL 1984 On the androgen microenvironment of maturing spermatozoa. Endocrinology 115 1925-1925. (doi:10.1210/endo-115-5-1925)

Vauti F, Prochnow BR, Freese E, Ramasamy SK, Ruiz P \& Arnold HH 2007 Arp3 is required during preimplantation development of the mouse embryo. FEBS Letters 581 5691-5697. (doi:10.1016/j.febslet. 2007.11.031)

Vogl AW, Vaid KS \& Guttman JA 2008 The Sertoli cell cytoskeleton. Advances in Experimental Medicine and Biology 636 186-211.

Vogl AW, Young JS \& Du M 2013 New insights into roles of tubulobulbar complexes in sperm release and turnover of blood-testis barrier. International Review of Cell and Molecular Biology 303 319-355. (doi:10.1016/B978-0-12-407697-6.00008-8)

Wan HT, Mruk DD, Li SY, Mok KW, Lee WM, Wong CK \& Cheng CY 2013 p-FAK-Tyr ${ }^{397}$ regulates spermatid adhesion in the rat testis via its effects on F-actin organization at the ectoplasmic specialization. American Journal of Physiology. Endocrinology and Metabolism 305 E687-E699. (doi:10.1152/ajpendo.00254.2013)

Wan HT, Mruk DD, Tang El, Xiao X, Cheng YH, Wong EW, Wong CK \& Cheng CY 2014 Role of non-receptor protein tyrosine kinases in spermatid transport during spermatogenesis. Seminars in Cell \& Developmental Biology 30 65-74. (doi:10.1016/j.semcdb.2014.04.013)

Weber JE \& Russell LD 1987 A study of intercellular bridges during spermatogenesis in the rat. American Journal of Anatomy 180 1-24. (doi:10.1002/aja.1001800102)

Weber JE, Russell LD, Wong V \& Peterson RN 1983 Three dimensional reconstruction of a rat stage $V$ Sertoli cell: II. Morphometry of SertoliSertoli and Sertoli-germ cell relationships. American Journal of Anatomy 167 163-179. (doi:10.1002/aja.1001670203)

Wiebe J, Kowalik A, Gallardi R, Egeler O \& Clubb B 2000 Glycerol disrupts tight junction-associated actin microfilaments, occludin, and microtubules in Sertoli cells. Journal of Andrology 21 625-635.

Wong EW \& Cheng CY 2013 NC1 domain of collagen a3(IV) derived from the basement membrane regulates Sertoli cell blood-testis barrier dynamics. Spermatogenesis 3 e25465. (doi:10.4161/spmg. 25465)

Xiao X, Mruk DD, Lee WM \& Cheng CY 2011 c-Yes regulates cell adhesion at the blood-testis barrier and the apical ectoplasmic specialization in the seminiferous epithelium of rat testes. International Journal of Biochemistry \& Cell Biology 43 651-665. (doi:10.1016/j.biocel.2011. 01.008)

Xiao X, Mruk DD, Cheng FL \& Cheng CY 2012 c-Src and c-Yes are two unlikely partners of spermatogenesis and their roles in blood-testis barrier dynamics. Advances in Experimental Medicine and Biology 763 295-317.

Xiao X, Mruk DD \& Cheng CY 2013 c-Yes regulates cell adhesion at the apical ectoplasmic specialization-blood-testis barrier axis via its effects on protein recruitment and distribution. American Journal of Physiology. Endocrinology and Metabolism 304 E145-E159. (doi:10.1152/ajpendo. 00422.2012)

Xiao X, Mruk DD, Wong CK \& Cheng CY 2014a Germ cell transport across the seminiferous epithelium during spermatogenesis. Physiology 29 286-298. (doi:10.1152/physiol.00001.2014)

Xiao X, Mruk DD, Wong EW, Lee WM, Han D, Wong CK \& Cheng CY $2014 b$ Differential effects of c-Src and c-Yes on the endocytic vesiclemediated trafficking events at the Sertoli cell blood-testis barrier: an in vitro study. American Journal of Physiology. Endocrinology and Metabolism 307 E553-E562. (doi:10.1152/ajpendo.00176.2014)

Xiao X, Mruk DD, Tang EI, Massarwa R, Mok KW, Li N, Wong CK, Lee WM, Snapper SB, Shilo BZ et al. 2014C N-WASP is required for structural integrity of the blood-testis barrier. PLoS Genetics 10 e1004447. (doi:10.1371/journal.pgen.1004447) 
Xu W, Baribault H \& Adamson ED 1998 Vinculin knockout results in heart and brain defects during embryonic development. Development 125 327-337.

Yamakita Y, Matsumura F \& Yamashiro S 2009 Fascin1 is dispensable for mouse development but is favorable for neonatal survival. Cell Motility and the Cytoskeleton 66 524-534. (doi:10.1002/cm.20356)

Yan HH, Mruk DD, Lee WM \& Cheng CY 2008a Blood-testis barrier dynamics are regulated by testosterone and cytokines via their differential effects on the kinetics of protein endocytosis and recycling in Sertoli cells. FASEB Journal 22 1945-1959. (doi:10.1096/fj.06070342)

Yan HH, Mruk DD, Wong EW, Lee WM \& Cheng CY 2008b An autocrine axis in the testis that coordinates spermiation and blood-testis barrier restructuring during spermatogenesis. PNAS 105 8950-8955. (doi:10.1073/pnas.0711264105)
Yule TD, Montoya GD, Russell LD, Williams TM \& Tung KS 1988 Autoantigenic germ cells exist outside the blood testis barrier. Journal of Immunology 141 1161-1167.

Zheng Y \& Iglesias PA 2013 Nucleating new branches from old. Cell 152 669-670. (doi:10.1016/j.cell.2013.01.040)

Zhou F, Leder P, Zuniga A \& Dettenhofer M 2009 Formin1 disruption confers oligodactylism and alters Bmp signaling. Human Molecular Genetics 18 2472-2482. (doi:10.1093/hmg/ddp185)

Received 2 October 2015

First decision 5 November 2015

Revised manuscript received 10 November 2015

Accepted 1 December 2015 